\title{
Operating Conditions and Composition Effect on the Hydrogenation of Carbon Dioxide Performed over $\mathrm{CuO} / \mathrm{ZnO} / \mathrm{Al}_{2} \mathrm{O}_{3}$ Catalysts
}

\author{
Djaouida Allam*, Salem Cheknoun, Smain Hocine \\ Laboratoire de Chimie Appliquée et de Génie Chimique, Université M. Mammeri de Tizi-Ouzou, \\ BP.17 R.P 15000 Tizi-Ouzou, Algeria
}

Received: 20th October 2018; Revised: $2^{\text {nd }}$ July 2019; Accepted: 9th July 2019;

Available online: 30th September 2019; Published regularly: December 2019

\section{Abstract}

A series of catalysts constituted of mixed copper and zinc oxides supported on alumina were prepared by co-precipitation method. The cooper content was in the $10-90 \mathrm{wt} . \%$ range. Their catalytic behavior in the hydrogenation of carbon dioxide to methanol was investigated at high pressure (up to 75 bars). The catalysts were characterized by elemental analysis, $\mathrm{N}_{2}$-adsorption, $\mathrm{N}_{2} \mathrm{O}$-chemisorptions, and X-ray diffraction (XRD). The catalysts showed a clear activity in the hydrogenation reaction that could be correlated to the surface area of the metallic copper and to the reaction pressure. The $\mathrm{CuO} / \mathrm{ZnO} / \mathrm{Al}_{2} \mathrm{O}_{3}$ catalyst with a $\mathrm{Cu} / \mathrm{Zn} / \mathrm{Al}$ weight ratio of 60/30/10, exhibits the highest carbon dioxide conversion and methanol selectivity. Finally, a mechanism pathway has been proposed on copper active sites of $\left(\mathrm{Cu}^{\mathrm{O}} / \mathrm{Cu}^{\mathrm{I}}\right)$ oxidation state. Copyright $\mathbb{C} 2019$ BCREC Group. All rights reserved

Keywords: carbon dioxide; hydrogenation; methanol; $\mathrm{CuO} / \mathrm{ZnO} / \mathrm{Al}_{2} \mathrm{O}_{3}$ catalysts

How to Cite: Allam, D., Cheknoun, S., Hocine, S. (2019) Operating Conditions and Composition Effect on the Hydrogenation of Carbon Dioxide Performed over $\mathrm{CuO} / \mathrm{ZnO} / \mathrm{Al}_{2} \mathrm{O}_{3}$ Catalysts. Bulletin of Chemical Reaction Engineering \& Catalysis, 14(3): 604-613 (doi:10.9767/bcrec.14.3.3451.604-613)

Permalink/DOI: https://doi.org/10.9767/bcrec.14.3.3451.604-613

\section{Introduction}

Methanol is an important intermediate in the petrochemical industry used in the production of a variety of products, including gasoline and alternative raw materials for the production of olefin such as ethylene and propylene [1]. The increasing demand for methanol has drawn considerable attention in enhancing its production. Currently, methanol is industrially produced starting from $\mathrm{CO} / \mathrm{CO}_{2} / \mathrm{H}_{2}$ mixture over $\mathrm{CuO} / \mathrm{ZnO} / \mathrm{Al}_{2} \mathrm{O}_{3}$ catalysts operating at $50-100$ bars, and $220-300{ }^{\circ} \mathrm{C}[2]$. If the $\mathrm{CuO} / \mathrm{ZnO} / \mathrm{Al}_{2} \mathrm{O}_{3}$ catalyst exhibits high activity in the methanol

* Corresponding Author.

E-mail: allamdjaouida788@gmail.com (D. Allam); Tel: +213-542414631 synthesis from syngas, its catalytic activity in the hydrogenation of pure $\mathrm{CO}_{2}$ results very poor [3-5]. In order to improve the catalytic performance for methanol synthesis from $\mathrm{H}_{2} / \mathrm{CO}_{2}$, it is important to synthesize and develop new catalysts with a higher activity in the carbon dioxide hydrogenation reaction. Moreover, being $\mathrm{CO}_{2}$ one of the most common greenhouse gases, to develop new and efficient industrial routes for its valorization is extremely interesting from the economic and environmental point of view.

Therefore, numerous investigations and great efforts have been done in preparing ameliorate catalysts for the hydrogenation of carbon dioxide [6-11]. Most researchers consider that the $\mathrm{CuO} / \mathrm{ZnO}$ system is responsible for the activity of the copper phase $[12,13]$. For this reason, the majority of the modified catalysts still con- 
tain $\mathrm{Cu}-\mathrm{Zn}$ oxides as main constituents, and others components can be added in order to modify the catalytic properties.

In this optic, $\mathrm{CuO} / \mathrm{ZnO}$ catalysts have been modified by addition of different metals oxides such as $\mathrm{PdO}, \mathrm{CeO}_{2}, \mathrm{ZrO}_{2}, \mathrm{Ga}_{2} \mathrm{O}_{3}, \mathrm{Al}_{2} \mathrm{O}_{3}, \mathrm{Cr}_{2} \mathrm{O}_{3}$ and $\mathrm{V}_{2} \mathrm{O}_{5}$ [14-32]. It was found that the support or promoters act only on the $\mathrm{Cu}$ dispersion to increase the specific activity. Copper oxide alone is not very active in methanol production, but, when mixed with $\mathrm{ZnO}$, a combined oxide is formed, and the synergic-activity end up in improved catalytic performances, if compared to those of the separate oxides. Consequently, many studies have been focused on the identification of the structure and the nature of the active sites of the catalyst surface. It was suggested that the predominant active site for methanol synthesis were $\mathrm{Cu}-\mathrm{Zn}$ pair [33,34], $\mathrm{Cu}^{+}$ions [35,36], $\mathrm{Cu}^{0} \mathrm{Cu}^{+}[37,38]$, or metallic copper $[39,40]$.

The aim of the present research is to study of the influence of $\mathrm{CuO} / \mathrm{ZnO}$ weight ratios, surface property, and reaction pressure on the activity of $\mathrm{CuO} / \mathrm{ZnO} / \mathrm{Al}_{2} \mathrm{O}_{3}$ catalyst in the synthesis of methanol starting from $\mathrm{CO}_{2} / \mathrm{H}_{2}$. The listed parameters play indeed an important role in driving the catalytic performance of such mixed oxides catalyst.

\section{Materials and Methods}

\subsection{Catalysts Preparation}

All the chemicals were purchased from Sigma-Aldrich (St. Louis, MO, USA) and used without further purification. A series of

Table 1. Infra-red absorption bands of catalysts

\begin{tabular}{lll}
\hline Catalysts & \multicolumn{1}{c}{$\begin{array}{c}\text { Adsorption } \\
\text { bands }\left(\mathrm{cm}^{-1}\right)\end{array}$} & \multicolumn{1}{c}{ Assignment } \\
\hline $\mathrm{C}_{1}$ & $1385(\mathrm{~s})$ & Metallic carbonates \\
& $1497-1631(\mathrm{l})$ & Metallic carbonates \\
& $3442(\mathrm{l})$ & $\mathrm{H}_{2} \mathrm{O}(\mathrm{O}-\mathrm{H})$ \\
\hline $\mathrm{C}_{2}$ & $1385(\mathrm{~s})$ & Metallic carbonates \\
& $1631(\mathrm{l})$ & Metallic carbonates \\
& $3442(\mathrm{l})$ & Eau \\
\hline $\mathrm{C}_{3}$ & $1385(\mathrm{~s})$ & Metallic carbonates \\
& $1497-1631(\mathrm{l})$ & Metallic carbonates \\
& $3442(\mathrm{l})$ & O-H $\left(\mathrm{H}_{2} \mathrm{O}\right)$ \\
\hline $\mathrm{C}_{4}$ & $1385(\mathrm{~s})$ & Metallic carbonates \\
& $3442(\mathrm{l})$ & O-H $\left(\mathrm{H}_{2} \mathrm{O}\right)$ \\
\hline $\mathrm{C}_{5}$ & $1385(\mathrm{~s})$ & Metallic carbonates \\
& $1631(\mathrm{l})$ & Metallic carbonates \\
& $3442(\mathrm{l})$ & O-H $\left(\mathrm{H}_{2} \mathrm{O}\right)$ \\
\hline
\end{tabular}

- S : Strong

- 1 : Low intensity
$\mathrm{CuO} / \mathrm{ZnO} / \mathrm{Al}_{2} \mathrm{O}_{3}$ catalysts with 10 wt. $\%$ of $\mathrm{Al}_{2} \mathrm{O}_{3}$ and different $\mathrm{CuO} / \mathrm{ZnO}$ weight ratios were prepared by co-precipitation method on $10 \mathrm{wt} \%$ alumina [41]. The copper and zinc nitrate precursors $\mathrm{Cu}\left(\mathrm{NO}_{3}\right)_{2} .2 .5 \mathrm{H}_{2} \mathrm{O}(98 \%$ purity $)$ and $\mathrm{Zn}\left(\mathrm{NO}_{3}\right)_{2} .6 \mathrm{H}_{2} \mathrm{O}(99 \%$ purity) were dissolved in deionized water and sodium carbonate $\mathrm{Na}_{2} \mathrm{CO}_{3}$ (99.5\% purity) was used as precipitating agent. Prior to precipitation, the estimated $10 \mathrm{wt} . \%$ of alumina, $\mathrm{Al}_{2} \mathrm{O}_{3}$ (98\% purity) was added to the solution and the slurry was stirred and kept at $85^{\circ} \mathrm{C}$. The addition of sodium carbonate increased the $\mathrm{pH}$ to 7 , allowing the coprecipitation of $\mathrm{Cu}$ and $\mathrm{Zn}$ hydroxides on the alumina surface. Then, the obtained solid material was aged during $2 \mathrm{~h}$ under intensive stirring. In the next step, sodium and nitrate ions were thoroughly removed by washing the solid with redistilled water (6 times) until the total elimination of $\mathrm{Na}^{+}$and $\mathrm{NO}_{3}{ }^{-}$ions. Analysis of the filtrate by electrical conductivity confirmed this result.

To avoid agglomeration of the $\mathrm{CuO}$ and $\mathrm{ZnO}$ particles in the $\mathrm{CuO}-\mathrm{ZnO}$ solid solution, the dried precipitate was calcined in air at $350{ }^{\circ} \mathrm{C}$ for $12 \mathrm{~h}$. Several studies have shown that when the calcination temperature exceeded $350{ }^{\circ} \mathrm{C}$, specific area and catalytic activity decreased. After calcination, all catalysts were characterized by IR spectroscopy (Table 1), only $\mathrm{O}-\mathrm{H}$ stretching and metallic carbonates vibration band were observed.

\subsection{Catalysts Characterization}

X-ray patterns were collected on PANATICAL MPD X'Pert Pro diffractometer operating with $\mathrm{Cu}-\mathrm{K} \alpha$ radiation $(\mathrm{K} \alpha=0.15418 \mathrm{~nm})$ and equipped with an X' Accelerator. The real-time multiple strip pattern was collected at $295 \mathrm{~K}$ in the $5^{\circ}-70^{\circ} 2 \theta$ range with a step of $0.017^{\circ} 2 \theta$ and a time /step of $220 \mathrm{sec}$; the total collecting time was about $2 \mathrm{~h}$.

The copper and zinc content were determined using an AAS 6800 spectrometer (Shimadzu). The specific surface areas of the alumina support and the obtained catalyst were measured by nitrogen adsorption at -196 ${ }^{\circ} \mathrm{C}$ by applying the BET method and using a Quantachrome apparatus. The metallic copper surface area was measured by the decomposition of $\mathrm{N}_{2} \mathrm{O}$ at $90{ }^{\circ} \mathrm{C}$ [42-44] on the surface of metallic copper by the following reaction:

$$
2 \mathrm{Cu}_{(\mathrm{s})}+\mathrm{N}_{2} \mathrm{O}_{(\mathrm{g})} \rightarrow \mathrm{N}_{2(\mathrm{~g})}+\mathrm{Cu}_{2} \mathrm{O}_{(\mathrm{s})}
$$


The pulse titration technique was employed and a thermal conductivity detector (TCD) was used to detect the amount of $\mathrm{N}_{2} \mathrm{O}$ consumed.

\subsection{Catalytic Tests}

The catalytic tests have been performed in a continuous tubular flow fixed-bed microreactor at different reaction pressures and at constant temperature of $230{ }^{\circ} \mathrm{C}$ for all catalysts. For the most active catalyst (C4) further investigations at different temperature (in the $170-270{ }^{\circ} \mathrm{C}$ range) have been performed. Prior to reaction, the catalyst $(0.5 \mathrm{~g})$ was reduced in $\mathrm{H}_{2}$ flow (1.3 L.h $\left.{ }^{-1}\right)$. The reduction program consisted in an increment of the temperature from room temperature to $350{ }^{\circ} \mathrm{C}$ at $10^{\circ} \mathrm{C} \cdot \mathrm{min}^{-1}$ and of a plateau to $350{ }^{\circ} \mathrm{C}$ for $8 \mathrm{~h}$. After the reduction step, the reactor was fed with the reaction mixture: $\mathrm{CO}_{2} / \mathrm{H}_{2}=1 / 3$. The total flow rate was in the 0.3$3.6 \mathrm{~L} . \mathrm{h}^{-1}$ range and the tested operating pressures were: $1,20,35,50$, and 75 bar, respectively. The reaction mixture and products were analyzed on line by using gas chromatographs equipped with TCD and FID detectors and Carbosieve and Porapak Q columns, respectively. The products, detected in the stream flow exiting form the reactor during $\mathrm{CO}_{2}$ hydrogenation

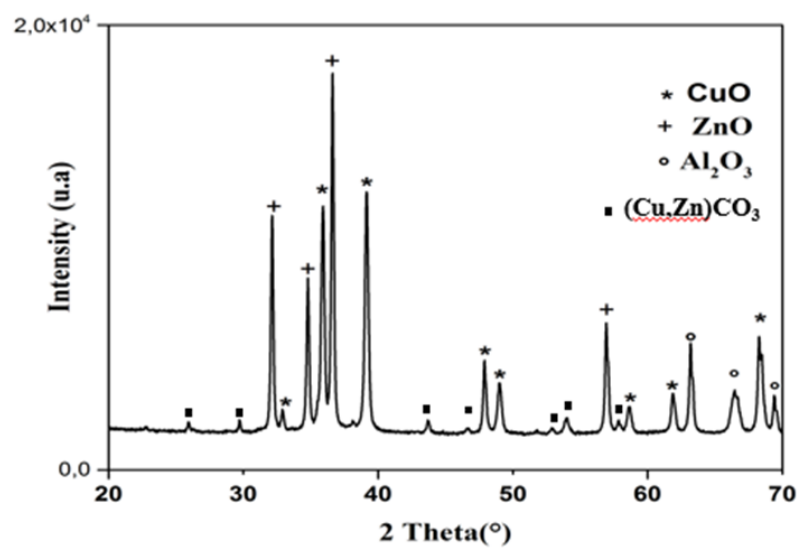

Figure 1. XRD pattern of $\mathrm{CuO} / \mathrm{ZnO} / \mathrm{Al}_{2} \mathrm{O}_{3}$ catalyst after calcination on $\mathrm{CuO} / \mathrm{ZnO} / \mathrm{Al}_{2} \mathrm{O}_{3}$ catalysts, were almost exclusively constituted of methanol and carbon monoxide. Only traces of methane could be observed. Methanol and carbon monoxide selectivity and $\mathrm{CO}_{2}$ conversion were calculated using the following equations:

$$
\begin{aligned}
& \mathrm{CO}_{2} \text { conversion }(\%)=\frac{s_{\mathrm{CO}_{2} \text { in }}-s_{\mathrm{CO}_{2} \text { out }}}{s_{\mathrm{CO}_{2} \text { in }}} \times 100 \\
& \mathrm{CH}_{3} \mathrm{OH} \text { selectivity }(\%)=\frac{s_{\mathrm{CH}_{3} \mathrm{OH} \text { out }}}{\mathrm{CO}_{2} \text { conversion }} \times 100 \\
& \mathrm{CO} \text { selectivity }(\%)=\frac{s_{\text {CO out }}}{\mathrm{CO}_{2} \text { conversion }} \times 100
\end{aligned}
$$

\section{Results and Discussion}

3.1 Textural properties of $\mathrm{CuO} / \mathrm{ZnO} / \mathrm{Al}_{2} \mathrm{O}_{3}$ catalysts

\subsection{1 $\mathrm{N}_{2}$ adsorption-desorption}

The BET surface area of the $\mathrm{CuO} / \mathrm{ZnO} / \mathrm{Al}_{2} \mathrm{O}_{3}$ catalysts with different $\mathrm{Cu} / \mathrm{Zn}$ theoretical and experimental weight ratios are summarized in Table 2 . The surface area significantly decreases when increasing the $\mathrm{Cu} / \mathrm{Zn}$ ratio. The increase of $\mathrm{Cu} / \mathrm{Zn}$ ratio should be responsible for the decrease of surface area. The growth of crystal grain or agglomeration of particles with the increase of $\mathrm{Cu} / \mathrm{Zn}$ ratio should be responsible for the decrease of surface area. At the opposite, the metallic copper surface area increased with the $\mathrm{Cu} / \mathrm{Zn}$ ratio, suggesting that the $\mathrm{Cu}$-containing phase is mainly distributed on the surface of the composite.

\subsubsection{XRD analysis}

The XRD patterns of the calcined $\mathrm{CuO}$ $\mathrm{ZnO} / \mathrm{Al}_{2} \mathrm{O}_{3}$ samples with different $\mathrm{Cu} / \mathrm{Zn}$ weight ratios are constituted of mixtures of $\mathrm{CuO}, \mathrm{ZnO}$ and $\mathrm{Al}_{2} \mathrm{O}_{3}$ (Figure 1). The Bragg angles $2 \theta$ peaks of $32.5,35.5,38.7,48.7,58.3$, $61.5,65.8$, and $66.2^{\circ}[45-46]$ was attributed to

Table 2. Textural properties and catalytic performance of different $\mathrm{CuO} / \mathrm{ZnO} / \mathrm{Al}_{2} \mathrm{O}_{3}$ catalysts

\begin{tabular}{cccccccc}
\hline Catalyst & $\begin{array}{c}\text { Theoretical } \\
\text { Cu/Zn/Al (at \%) }\end{array}$ & $\begin{array}{c}\text { Experimental } \\
\text { Cu/Zn }(\text { at \%) }\end{array}$ & $\begin{array}{c}S_{\mathrm{Cu}} \\
\left(\mathrm{m}^{2} / \mathrm{g}\right)\end{array}$ & $\begin{array}{c}S_{\mathrm{BET}} \\
\left(\mathrm{m}^{2} / \mathrm{g}\right)\end{array}$ & $\begin{array}{c}X_{\mathrm{CO} 2} \\
(\%)\end{array}$ & $\begin{array}{c}S_{\mathrm{CO}} \\
(\%)\end{array}$ & $\begin{array}{c}S_{\mathrm{CH} 3 \mathrm{OH}} \\
(\%)\end{array}$ \\
\hline $\mathrm{C} 1$ & $10 / 80 / 10$ & $8.70 / 81.30$ & 1.12 & 59 & 6.0 & 98.4 & 1.6 \\
$\mathrm{C} 2$ & $40 / 50 / 10$ & $39.85 / 49.71$ & 2.52 & 42 & 7.5 & 97.9 & 2.1 \\
$\mathrm{C} 3$ & $50 / 40 / 10$ & $48.69 / 38.37$ & 3.56 & 33 & 9.0 & 96.5 & 3.5 \\
C4 & $60 / 30 / 10$ & $59.15 / 28.14$ & 4.45 & 21 & 11.4 & 94.7 & 5.3 \\
$\mathrm{C} 5$ & $70 / 20 / 10$ & $69.34 / 18.66$ & 5.60 & 14 & 13.0 & 97.8 & 2.2 \\
\hline
\end{tabular}

Reaction conditions $\mathrm{P}=1$ bar, $\mathrm{T}_{\mathrm{R}}=230{ }^{\circ} \mathrm{C}, \mathrm{CO}_{2} / \mathrm{H}_{2}=1 / 3$ (molar ratio); $\mathrm{X}_{\mathrm{CO} 2}$ : $\mathrm{CO}_{2}$ conversion; S: Selectivity 
$\mathrm{CuO}$ and consistent with the characteristic peaks of $\mathrm{ZnO}$ at of $31.7,34.1,36.2$, and $56.9^{\circ}$ [46], and those of alumina at $2 \theta$ of 66.5 and $68.2^{\circ} 2 \theta$ [47]. Increasing of $\mathrm{Cu} / \mathrm{Zn}$ ratio, the diffraction peaks of $\mathrm{CuO}$ become stronger and sharper, while the peaks attributed to $\mathrm{ZnO}$ have the opposite variation trend. The small peaks at $2 \theta: 29.1,44.3$, and 54.8 are attributed to the undecomposed metallic carbonates, such as: $\mathrm{CuCO}_{3}$ and/or $\mathrm{ZnCO}_{3}$.

\subsection{Catalytic Properties of $\mathrm{CuO} / \mathrm{ZnO} / \mathrm{Al}_{2} \mathrm{O}_{3}$ Cat-} alyst

\subsubsection{Relation between catalytic performance} and $S_{\mathrm{Cu}}$

The results of the $\mathrm{CO}_{2}$ hydrogenation over the various $\mathrm{CuO} / \mathrm{ZnO} / \mathrm{Al}_{2} \mathrm{O}_{3}$ catalysts are given in Table 2. The selectivity to methanol increased with the metallic copper surface area for the samples containing 10-60\% of copper, while it decreased when the copper content exceeded $60 \%$, although the metallic copper surface area was even higher, a result that is consistent with other reports $[45,48,49]$. This can be explained by the positive synergetic effect obtained by the contact between copper and zinc oxides. On the other hand, the conversion of $\mathrm{CO}_{2}$ continuously increased by increasing the $\mathrm{Cu} / \mathrm{Zn}$ weight ratios, while the selectivity to $\mathrm{CO}$ decreased with the $\mathrm{Cu} / \mathrm{Zn}$ weight ratios augmentation, for the catalysts containing from 10 to $60 \%$ of copper content, but increased when the copper content exceeded $60 \%$ [48]. The effect of metallic cooper surface area on the $\mathrm{CO}_{2}$ conversion at $230^{\circ} \mathrm{C}$ is shown in Figure 2. With increasing the $\mathrm{Cu} / \mathrm{Zn}$ weight ratios, the metallic cooper surface area increased and the $\mathrm{CO}_{2}$ conversion was linearly enhanced. This indicated that the $\mathrm{CO}_{2}$ conversion is directly proportional

Table 3. Effect of temperature on the C4 catalyst performance

\begin{tabular}{cccc}
\hline $\mathrm{T}\left({ }^{\circ} \mathrm{C}\right)$ & $\begin{array}{c}\mathrm{CO}_{2} \\
\text { conversion } \\
(\%)\end{array}$ & $\begin{array}{c}\mathrm{CO} \\
\text { selectivity } \\
(\%)\end{array}$ & $\begin{array}{c}\mathrm{CH}_{3} \mathrm{OH} \\
\text { selectivity } \\
(\%)\end{array}$ \\
\hline 170 & 2.60 & 84.00 & 16.00 \\
190 & 5.00 & 90.86 & 9.14 \\
210 & 7.16 & 93.72 & 7.28 \\
230 & 11.4 & 94.66 & 5.34 \\
250 & 16.4 & 95.87 & 4.13 \\
280 & 19.0 & 96.90 & 3.10 \\
\hline
\end{tabular}

Reaction conditions flow $=2 \mathrm{~L} \cdot \mathrm{h}^{-1}, \mathrm{P}=1 \mathrm{bar}, \mathrm{CO}_{2} / \mathrm{H}_{2}=1 / 3$ (molar ratio) to the surface area of metallic copper. These results confirm that there must be some other factors affecting the catalytic performance during the synthesis of methanol from $\mathrm{CO}_{2} / \mathrm{H}_{2}$. Apparently, $\mathrm{Cu}^{0}$ atoms are the active sites in the dissociation of $\mathrm{CO}_{2}$ to $\mathrm{CO}$ and $\mathrm{Cu}-\mathrm{O}-\mathrm{Cu}$ species [50-53]. The dissociation reaction is the follows:

$$
\mathrm{CO}_{2(\mathrm{~g})}+2 \mathrm{Cu}^{0} \leftrightarrow \mathrm{CO}(\mathrm{g})+\mathrm{Cu}-\mathrm{O}-\mathrm{Cu}
$$

The presence of surface oxygen $(\mathrm{Cu}-\mathrm{O}-\mathrm{Cu})$ enhances both the adsorption of $\mathrm{CO}_{2}$ and of $\mathrm{H}_{2}$. The new created $\mathrm{Cu}-\mathrm{O}-\mathrm{Cu}$ active site enhances both the adsorption of $\mathrm{CO}_{2}$ and the formation of monodentate carbonate ( $\mathrm{Cu}-\mathrm{O}-\mathrm{CO}-\mathrm{O}-\mathrm{Cu}$ ) species that, after hydrogenation, lead to the formation of monodentate formate (Cu-O$\mathrm{CH}=\mathrm{O}$ ), which is the key intermediate in methanol production. The $\mathrm{CuO} / \mathrm{ZnO} / \mathrm{Al}_{2} \mathrm{O}_{3}$ catalyst with a $\mathrm{Cu} / \mathrm{Zn} / \mathrm{Al}$ weight ratio of $60 / 30 / 10$ exhibited the highest selectivity $(5.34 \%)$ to methanol at $230{ }^{\circ} \mathrm{C}$.

\subsubsection{Temperature effect}

Table 3, illustrates the effects of temperature on $\mathrm{CO}_{2}$ hydrogenation reaction at atmospheric pressure and stoichiometric feed ratio $\left(\mathrm{H}_{2} / \mathrm{CO}_{2}=3\right)$. The product stream mostly contains $\mathrm{CO}$ and methanol at reaction temperature in the range between 170 and $270{ }^{\circ} \mathrm{C}$. Moreover, by increasing the temperature, the $\mathrm{CO}_{2}$ conversion and carbon monoxide selectivity was enhanced, while the methanol selectivity decreased simultaneously. At constant reaction pressure, a lower temperature leads to

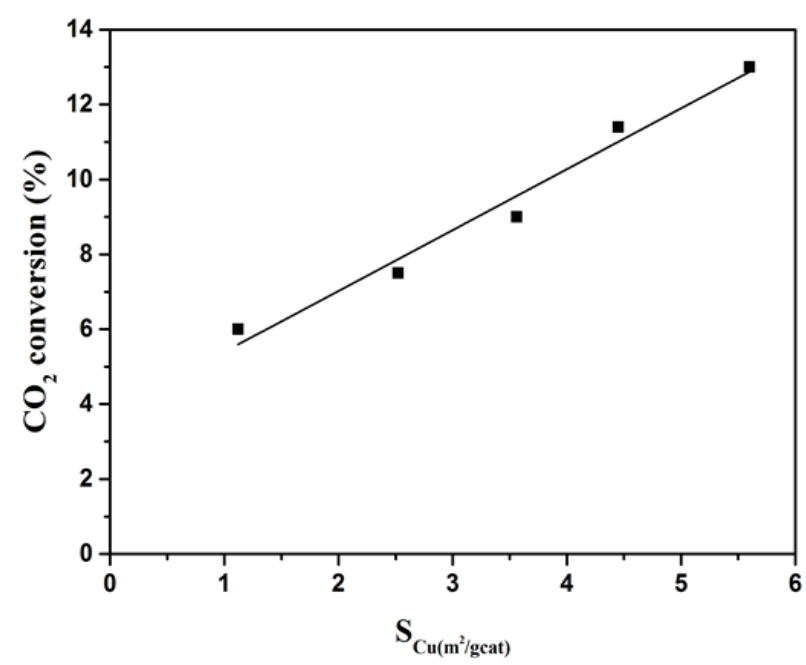

Figure 2. Correlation between the metallic copper surface area and the $\mathrm{CO}_{2}$ conversion at 230 ${ }^{\circ} \mathrm{C}, \mathrm{P}=1$ bar 
higher methanol selectivity. This result suggests that the formate, which is the main route for methanol synthesis is unstable at high temperature and decompose to $\mathrm{CO}$ and $\mathrm{H}_{2} \mathrm{O}$ through the reverse water gas shift (RWGS) reaction.

The effect of flow-rate variation was also tested at $0.6,1,1.4,2$, and $3.6 \mathrm{~L} / \mathrm{h}$, and $230{ }^{\circ} \mathrm{C}$. The data for the selectivity ratios during 10 hours on-stream with the $\mathrm{C} 4$ catalyst are reported in Figure 3. By increasing the flow-rate, the $\mathrm{CO}_{2}$ conversion and $\mathrm{CO}$ selectivity decreased, while the methanol selectivity considerably increased. A high flow-rate is favorable to methanol formation, whereas the $\mathrm{CO}$ formation is enhanced at low flow-rate.

The effects of the reaction pressure, on the activity and selectivity has been studied over the most active catalyst $\mathrm{C} 4\left(\mathrm{CuO} / \mathrm{ZnO} / \mathrm{Al}_{2} \mathrm{O}_{3}\right.$ :

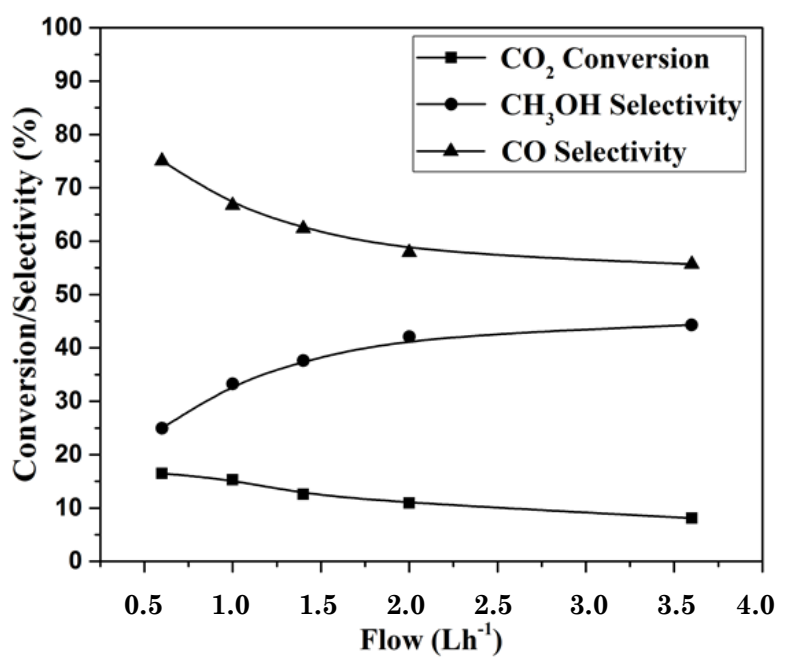

Figure 3. The effect of flow-rate on the Conversion/selectivity ratios at $230^{\circ} \mathrm{C}, \mathrm{P}=50 \mathrm{bar}$

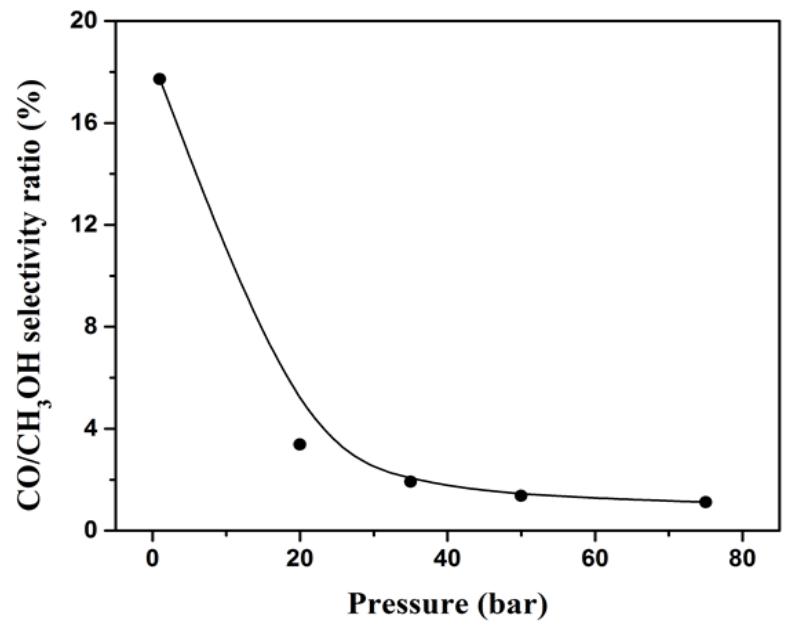

Figure 4. Influence of the pressure on the $\mathrm{CO} / \mathrm{CH}_{3} \mathrm{OH}$ selectivity ratios at $230{ }^{\circ} \mathrm{C}$
60/30/10) at the reaction temperature of $230{ }^{\circ} \mathrm{C}$ (Table 4). The conversion of carbon dioxide and methanol selectivity increased with the total pressure, while the carbon monoxide selectivity decreased by increasing the total pressures. At 75 bar, the methanol selectivity reached the maximum value. Such a behavior may be due to the decomposition of the formate species that is much lower at high pressure. Consequently, CO formation can be minimized increasing the pressure. The $\mathrm{CO} / \mathrm{CH}_{3} \mathrm{OH}$ selectivity ratios expressed as function of the pressure show the same trend that observed as a function of the flow-rate, Figure 4. Finally, high pressure and high flow-rate are favorable to methanol production, while they present the opposite effect on the $\mathrm{CO}$ formation.

3.3 Kinetics and Mechanism of Carbon Dioxide Hydrogenation

\subsubsection{The activation energy}

Overall, apparent activation energy can be determined from the effect of temperature on the rate for the $\mathrm{CO}_{2}$ hydrogenation reaction, with constant composition and pressure.

An Arrhenius type plot of ln (rate) is obtained from $\mathrm{CO}_{2}$ conversion to methanol with the reaction temperature $170,190,210,230$, 250 and $270{ }^{\circ} \mathrm{C}$ (Figure 5). The activation energy, obtained from the slope of the straight line, for fine powdered catalyst $\mathrm{CuO} / \mathrm{ZnO} / \mathrm{Al}_{2} \mathrm{O}_{3}$ $(\mathrm{Cu} / \mathrm{Zn} / \mathrm{Al}$ weight ratio of $60 / 30 / 10)$, corresponds to $38 \mathrm{~kJ} / \mathrm{mol}$ for the methanol synthesis from $\mathrm{CO}_{2}$ hydrogenation. The activation energy is lower than that on copper $\mathrm{Cu}$ (110 plane) $(67 \mathrm{~kJ} / \mathrm{mol})$ and on polycrystalline $\mathrm{Cu}$ (77 kJ/mol) [53-54].

Table 4. Effect of pressure on the $\mathrm{C} 4$ catalyst performance

\begin{tabular}{cccc}
\hline $\begin{array}{c}\text { Pressure } \\
\text { (bar) }\end{array}$ & $\begin{array}{c}\mathrm{CO}_{2} \\
\text { Conversion } \\
(\%)\end{array}$ & $\begin{array}{c}\mathrm{CO} \\
\text { Selectivity } \\
(\%)\end{array}$ & $\begin{array}{c}\mathrm{CH}_{3} \mathrm{OH} \\
\text { Selectivity } \\
(\%)\end{array}$ \\
\hline 01 & 11.4 & 94.7 & 05.3 \\
20 & 17.5 & 77.2 & 22.8 \\
35 & 19.0 & 65.8 & 34.2 \\
50 & 21.4 & 57.9 & 42.1 \\
75 & 23.0 & 52.9 & 47.1 \\
\hline
\end{tabular}

Reaction conditions flow $=2 \mathrm{~L} \cdot \mathrm{h}^{-1}, \mathrm{~T}_{\mathrm{R}}=230^{\circ} \mathrm{C}$, $\mathrm{CO}_{2} / \mathrm{H}_{2}=1 / 3$ (molar ratio) 


\subsubsection{Carbon dioxide hydrogenation mechanism}

The $\mathrm{CuO} / \mathrm{ZnO} / \mathrm{Al}_{2} \mathrm{O}_{3}$ catalytic system have been widely used in industry in the synthesis of methanol from syngas and then widely studied in the hydrogenation reaction of pure $\mathrm{CO}_{2}$ to methanol. In the literature the debate remains still open on the methanol synthesis mechanism and on the nature of catalytic active sites involved. Two types of reaction pathways have been identified in the literature for the hydrogenation of $\mathrm{CO}_{2}$ to methanol. The first consists in the direct hydrogenation of $\mathrm{CO}_{2}$ to methanol. The second pathway suggests that $\mathrm{CO}_{2}$ is firstly converted to CO (through the RWGS reaction), then to methanol. Several active sites configurations have been proposed, some authors, proposed that $\mathrm{Cu}^{+}$is the site active in methanol synthesis, for others the active species are constituted of $\mathrm{Cu}^{0}$ or of a mixture of $\mathrm{Cu}^{+}$and $\mathrm{Cu}^{0}$. It is often reported that methanol formation occurs preferentially on $\mathrm{Cu}^{+}$centers $[35,36]$, however, it seems that methanol formation is activated only in presence of $\mathrm{Cu}^{0}$ $[37,40]$.

Generally, methanol synthesis by $\mathrm{CO}_{2}$ hydrogenation over $\mathrm{CuO} / \mathrm{ZnO}$ based catalysts implicates three competitive reactions. The first reaction is the direct synthesis of methanol from $\mathrm{CO}_{2}$ :

$$
\mathrm{CO}_{2}+3 \mathrm{H}_{2} \rightarrow \mathrm{CH}_{3} \mathrm{OH}+\mathrm{H}_{2} \mathrm{O}
$$

The second one is the inter-conversion between carbon dioxide and carbon monoxide (RWGS reaction):

$$
\mathrm{CO}_{2(\mathrm{~g})}+\mathrm{H}_{2} \rightarrow \mathrm{CO}(\mathrm{g})+\mathrm{H}_{2} \mathrm{O}
$$

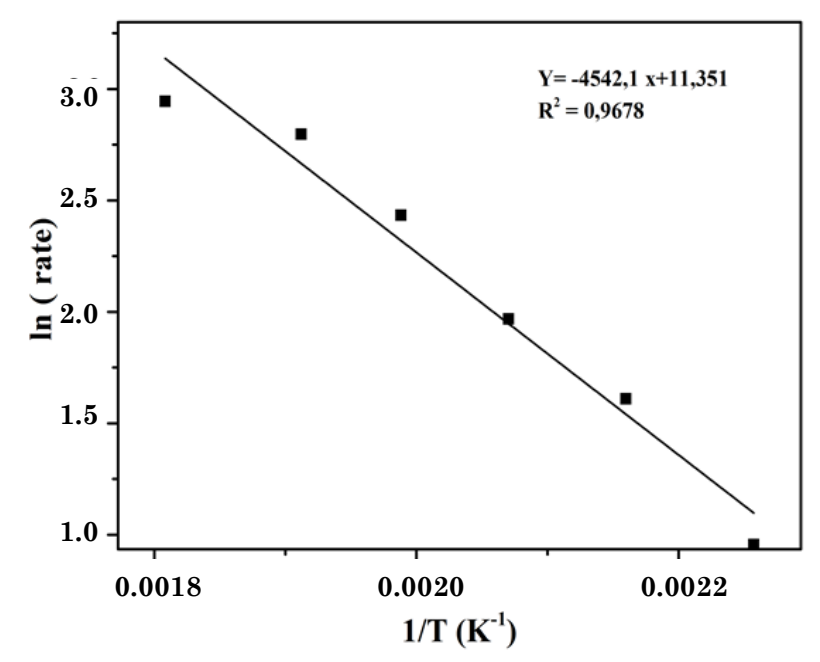

Figure 5. Arrhenius plot of $\mathrm{CO}_{2}$ conversion with the reaction conditions: flow $=2 \mathrm{~L} \cdot \mathrm{h}^{-1}, \mathrm{P}=$ 1 bar, $\mathrm{CO}_{2} / \mathrm{H}_{2}=1 / 3$ (molar ratio).
The third one is the synthesis of methanol from $\mathrm{CO}$ :

$$
\mathrm{CO}+2 \mathrm{H}_{2} \rightarrow \mathrm{CH}_{3} \mathrm{OH}
$$

By subtracting the reaction in Equation (7) from the reaction in Equation (6) results in:

$$
[\mathrm{CO}] /\left[\mathrm{CH}_{3} \mathrm{OH}\right]=k / P^{2} \mathrm{H} 2
$$

The $[\mathrm{CO}] /\left[\mathrm{CH}_{3} \mathrm{OH}\right]$ selectivity ratio is inversely proportional to the total pressure as displayed in Figure 4, for the reaction performed at 230 ${ }^{\circ} \mathrm{C}$. It is clear that at low pressure, the carbon monoxide is the main product, while, at high pressure, CO is transformed to methanol, demonstrating that carbon monoxide and methanol are produced from $\mathrm{CO}_{2}$ by parallel reactions.

This mechanism is also supported by the fact that methanol forms very fast if the pressure is high. Moreover, the increasing of the flow-rate also enhances methanol formation. When the $\mathrm{CO}_{2} / \mathrm{H}_{2}$ mixture was feed over the $\mathrm{CuO} / \mathrm{ZnO} / \mathrm{Al}_{2} \mathrm{O}_{3}$ catalysts, $\mathrm{CH}_{3} \mathrm{OH}$ was produced together with $\mathrm{CO}$ and $\mathrm{H}_{2} \mathrm{O}$. The methanol synthesis reaction, $\mathrm{CO}_{2}+3 \mathrm{H}_{2} \leftrightarrow \mathrm{CH}_{3} \mathrm{OH}+$ $\mathrm{H}_{2} \mathrm{O}$, takes place in parallel to the reverse water gas shift reaction, $\mathrm{CO}_{2}+\mathrm{H}_{2} \leftrightarrow \mathrm{CO}+\mathrm{H}_{2} \mathrm{O}$. The impact of pressure, flow-rate and temperature on the products formation suggests that $\mathrm{CH}_{3} \mathrm{OH}$ and $\mathrm{CO}$ are produced through parallel pathways. By increasing the pressure, the $\mathrm{CH}_{3} \mathrm{OH}$ selectivity increased, while the $\mathrm{CO}$ selectivity decreased. The same trend was observed by varying the feedstock flow-rate. At the contrary, by increasing the reaction temperature, the methanol selectivity decreased and the carbon monoxide selectivity increased. These observations suggest that methanol and carbon monoxide are directly formed starting from the surface formate $(\mathrm{O}-\mathrm{CH}=\mathrm{O})$ species that is formed via hydrogenation of $\mathrm{CO}_{2}$.

The proposed mechanism for carbon dioxide hydrogenation at high pressure suggests that the reaction between formate (HCOO) and hydrogen brings to the formation of dioxomethylene $\left(\mathrm{H}_{2} \mathrm{COO}\right)$. The dioxomethylene formation reaction may strongly compete with the decomposition reaction of formate to $\mathrm{CO}$. Hence, high pressures favor the methanol selectivity, as confirmed by the results reported in Table 3 . Pressure has a very strong influence on the production of methanol, probably due to the increasing of moles that characterize the involved reactions and that consequently shifts the equilibrium towards the condensation reaction. 
Previous works suggested that over copper based catalysts, the hydrogenation of carbon dioxide to methanol proceeds via the formation of the formate surface intermediate [53,56-58]. This reaction is usually considered the ratedetermining step. The idea was previously reported by Fujita and co-workers [59] whose used IR spectroscopy to study the chemisorption of $\mathrm{CO}_{2} / \mathrm{H}_{2}$ on a $\mathrm{CuO} / \mathrm{ZnO}$-based catalyst. The reaction intermediates observed on the catalyst surface were carbonate $\left(\mathrm{CO}_{3}{ }^{2}\right)$, formate ( $\mathrm{HCOO})$, dioxomethylene $\left(\mathrm{H}_{2} \mathrm{COO}\right)$, formaldehyde $\left(\mathrm{CH}_{2} \mathrm{O}\right)$, methoxy $\left(\mathrm{CH}_{3} \mathrm{O}^{-}\right)$species and the final product, $\mathrm{CH}_{3} \mathrm{OH}$. The adsorbed species detected on the catalyst (carbonates, formates and methoxy) are also in agreement with a similar study reported by Bailey et al. [60].

Chinchen et al. [61] proposed that the surface atomic oxygen $\mathrm{O}^{*}(\mathrm{Cu}-\mathrm{O}-\mathrm{Cu})($ a) plays an important role during the methanol synthesis by promoting the adsorption of $\mathrm{CO}_{2}$, and by participating in the hydrogenation step. Based on the observations just reported, a tentative mechanism is schematized in Figure 6, for the methanol synthesis from $\mathrm{CO}_{2} / \mathrm{H}_{2}$ over a $\mathrm{CuO} / \mathrm{ZnO}$ containing catalyst. At the first, the carbonate adsorption species (b) are produced by exposing the $\mathrm{CuO} / \mathrm{ZnO}$ catalyst surface to $\mathrm{CO}_{2} / \mathrm{H}_{2}$. Then the hydrogenation to formate $\left(\mathrm{HCOO}^{-}\right)(\mathrm{c})$, followed by the formation of dioxomethylene $\left(\mathrm{H}_{2} \mathrm{COO}\right)$ (f) and of methoxy $\left(\mathrm{CH}_{3} \mathrm{O}\right)$ species (g) take place to bring to the final product, methanol $\left(\mathrm{CH}_{3} \mathrm{OH}\right)$ (Sequence B). The $\mathrm{CO}$ is produced by decomposition of the monodentate and bidentate formate. In the same way than that of the formate decomposition, the decomposition of surface hydroxyl species leads to water formation (sequence $\mathrm{A}$ ).

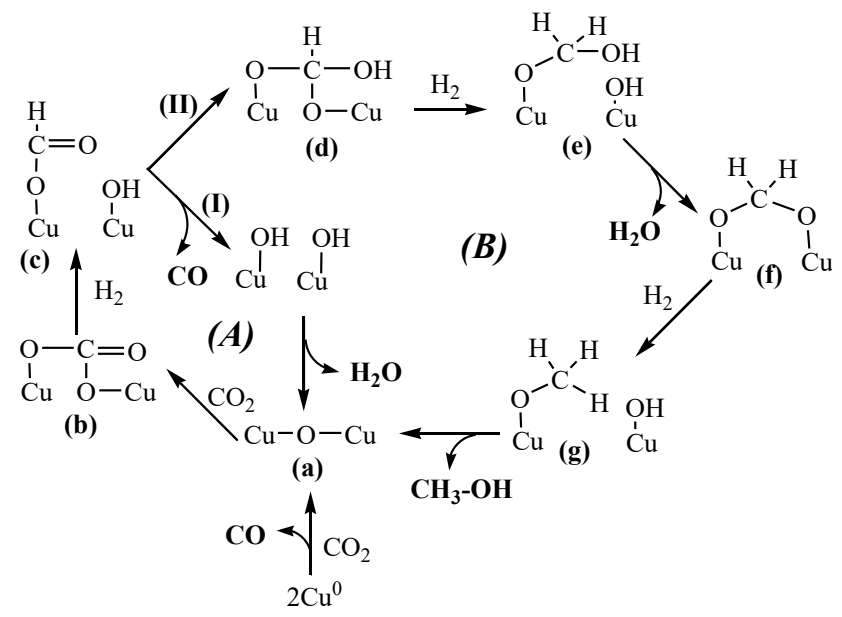

Figure 6. Reaction pathway of $\mathrm{CO}_{2}$ hydrogenation over $\mathrm{Cu}$ (I) centers

\section{Conclusions}

Methanol synthesis over $\mathrm{CuO} / \mathrm{ZnO} / \mathrm{Al}_{2} \mathrm{O}_{3}$ catalysts occurs via $\mathrm{CO}_{2}$ hydrogenation on the partially oxidized copper surface $\left(\mathrm{Cu}^{\mathrm{O}} / \mathrm{Cu}^{\mathrm{I}}\right) . \mathrm{CO}_{2}$ conversion and methanol selectivity strongly depend on the catalyst composition, pressure, reaction temperature and flow rate. High pressure and high flow-rate enhance the methanol formation. Besides a high reaction temperature favors the carbon monoxide production. The present results show the great influence of the catalyst composition and operating pressure on the kinetic and catalytic performances of $\mathrm{CuO} / \mathrm{ZnO} / \mathrm{Al}_{2} \mathrm{O}_{3}$ catalysts in the $\mathrm{CO}_{2} / \mathrm{H}_{2}$ reaction. Methanol is directly produced from $\mathrm{CO}_{2}$ whatever the pressure, while carbon monoxide can be produce by the decomposition of the formate at low pressure or directly from $\mathrm{CO}_{2}$ reduction.

\section{References}

[1] Vora, B.V., Marker, T.L., Barge, P.T., Nilsen, H.R., Kvisle, S., Fuglerud, T. (1997). Economic Route for Natural Gas Conversion to Ethylene and Propylene. Stud. In. Surf. Sci. Catal., 107: 87-98.

[2] Behrens, M. (2014). Heterogeneous Catalysis of $\mathrm{CO}_{2}$ Conversion to Methanol on Copper Surfaces. Angew. Chem. Int. Ed., 53: 1202212024.

[3] Inui, T., Hara, H., Takeguchi, T., Kim, J. (1997). Structure and function of Cu-based composite catalysts for highly effective synthesis of methanol by hydrogenation of $\mathrm{CO}_{2}$ and CO. Catal. Today., 36: 25-32.

[4] Ma, Y., Sun, Q., Wu, D., Fan, W., Zhang, Y., Deng, J. (1998). A practical approach for the preparation of high activity $\mathrm{Cu} / \mathrm{ZnO} / \mathrm{ZrO}_{2}$ catalyst for methanol synthesis from $\mathrm{CO}_{2}$ hydrogenation. Appl. Catal. A., 171: 45-55.

[5] Arena, F., Barbera, K., Italiano, G., Bonura, G., Spadaro, L., Frusteri, F. (2007). Synthesis, characterization and activity pattern of $\mathrm{Cu}-\mathrm{ZnO} / \mathrm{ZrO}_{2}$ catalysts in the hydrogenation of carbon dioxide to methanol. J. Catal., 249: 185-194.

[6] Koppel, R.A., Baiker, A. (1992). Copper/zirconia catalysts for the synthesis of methanol from carbon dioxide: Influence of preparation variables on structural and catalytic properties of catalysts. Appl. Catal., 84: 77-102.

[7] Satio, M., Fujitani, T., Takeuchi, M. (1996). Development of copper/zinc oxide-based multicomponent catalysts for methanol synthesis from carbon dioxide and hydrogen. Appl. Catal., 138: 311-318. 
[8] Brown, J.A., Homs, N., Bell, A.T. (1990). Hydrogenation of $\mathrm{CO}_{2}$ and $\mathrm{CO}_{2} / \mathrm{CO}$ mixtures over copper-containing catalysts. J. Catal., 124: 73-85.

[9] Lee, J.S., Moon, K.I., Lee, S.H., Lee, S.Y., Kim, Y.G. (1995). Modified $\mathrm{Cu} / \mathrm{ZnO} / \mathrm{Al}_{2} \mathrm{O}_{3}$ catalysts for methanol synthesis from $\mathrm{CO}_{2} / \mathrm{H}_{2}$ and $\mathrm{CO} / \mathrm{H}_{2}$. Catal. Lett., 34: 93-99.

[10] Frohlich, C., Koppel, R.A., Baiker, A., Kilo, M., Wokaun, A. (1993). Hydrogenation of carbon dioxide over silver promoted copper/zirconia catalysts. Appl. Catal., 106: 275293.

[11] Deng, J.F., Sun, Q., Zhang, Y.L., Wu, D., Chen, S.Y. (1996). A novel process for preparation of a $\mathrm{Cu} / \mathrm{ZnO} / \mathrm{Al}_{2} \mathrm{O}_{3}$ ultrafine catalyst for methanol synthesis from $\mathrm{CO}_{2}+\mathrm{H}_{2}$ : comparison of various preparation methods. Appl. Catal., 139: 75-85.

[12] Waugh, K.C. (2012). Methanol synthesis, Catal. Lett., 142: 1153-1166.

[13] Behrens, M., Studt, F., Kasatkin, I., Kühl, S., Hävecker, M., Abild-Pedersen, F., Zander, S., Girgsdies, F., Kurr, P., Kniep, B.L., Tovar, M., Fischer, R.W., Nørskov, J.K., Schlögl, R. (2012). The active site of methanol synthesis over $\mathrm{Cu} / \mathrm{ZnO} / \mathrm{Al}_{2} \mathrm{O}_{3}$ industrial catalysts. Sci., 336: 893-897.

[14] Fujitani, T., Saito, M., Kanai, Y., Takeuchi, M., Moria, K., Watanabe, T., Kawai, M., Kakumoto, T. (1993). Methanol synthesis from $\mathrm{CO}_{2}$ and $\mathrm{H}_{2}$ over $\mathrm{Cu} / \mathrm{ZnO} / \mathrm{Ga}_{2} \mathrm{O}_{3}$ catalyst. Chem. Lett., 22: 1079-1080.

[15] Fornero, E.L., Sanguineti, P.B., Chiavassa, D.L., Bonivardi, A.L. (2013). Performance of ternary $\mathrm{Cu}-\mathrm{Ga}_{2} \mathrm{O}_{3}-\mathrm{ZrO}_{2}$ catalysts in the synthesis of methanol using $\mathrm{CO}_{2}$-rich gas mixtures. Catal. Today., 213: 163-170.

[16] Ladera, R., Perez-Alonso, F.J. (2013). Catalytic valorization of $\mathrm{CO}_{2}$ via methanol synthesis with Ga-promoted $\mathrm{Cu}-\mathrm{ZnO}-\mathrm{ZrO}_{2}$ catalysts. Appl. Catal. B. Envir., 142: 241-248.

[17] Słoczyński, J., Grabowski, R., Olszewski, P., Kozłowska, A., Stoch, J., Lachowska, M., Skrzypek, J. (2006). Effect of metal oxide additives on the activity and stability of $\mathrm{Cu} / \mathrm{ZnO} / \mathrm{ZrO}_{2}$ catalysts in the synthesis of methanol from $\mathrm{CO}_{2}$ and $\mathrm{H}_{2}$. Appl. Catal. A. General., 310: 127-137.

[18] Toyir, J., Ramoirez, P., de la Piscina, P.R., Fierro, J.L.G., Homs, N. (2001). Catalytic performance for $\mathrm{CO}_{2}$ conversion to methanol of gallium-promoted copper-based catalysts: influence of metallic precursors. Appl. Catal. B. Envi., 34: 255-266.

[19] Arena, F., Mezzatesta, G., Zafarana, G., Trunfio, G., Frusteri, F., Spadaro, L. (2013). How oxide carriers control the catalytic functionali- ty of the $\mathrm{Cu}-\mathrm{ZnO}$ system in the hydrogenation of $\mathrm{CO}_{2}$ to methanol. Catal. Today., 210: 39-46.

[20] Bonura, G., Arena, F., Mezzatesta, G., Cannilla, C., Spadaro, L., Frusteri, F. (2011). Role of the ceria promoter and carrier on the functionality of $\mathrm{Cu}$-based catalysts in the $\mathrm{CO}_{2}$-tomethanol hydrogenation reaction. Catal. Today., 171: 251-256.

[21] Pokrovski, K.A., Bell, A. (2006). Effect of dopants on the activity of $\mathrm{Cu} / \mathrm{M}_{0.3} \mathrm{Zr}_{0.7} \mathrm{O}_{2}(\mathrm{M}=$ $\mathrm{Ce}, \mathrm{Mn}$, and $\mathrm{Pr}$ ) for $\mathrm{CO}$ hydrogenation to methanol. J. Catal., 244: 43-51.

[22] Melian-Cabrera, I., Lopez Granados, M., Terreros, P., Fierro, J.L.G. (1998). $\mathrm{CO}_{2}$ hydrogenation over $\mathrm{Pd}$-modified methanol synthesis catalysts. Catal. Today., 45: 251-256.

[23] Zhang, L., Zhang, Y., Chen, S. (2012). Effect of promoter $\mathrm{SiO}_{2}, \mathrm{TiO}_{2}$ or $\mathrm{SiO}_{2}-\mathrm{TiO}_{2}$ on the performance of $\mathrm{CuO}-\mathrm{ZnO}-\mathrm{Al}_{2} \mathrm{O}_{3}$ catalyst for methanol synthesis from $\mathrm{CO}_{2}$ hydrogenation. Appl. Catal. A. General., 415: 118-123.

[24] Guo, X., Mao, D., Lu, G., Wang, S., Wu, G. (2011). The influence of La doping on the catalytic behavior of $\mathrm{Cu} / \mathrm{ZrO}_{2}$ for methanol synthesis from $\mathrm{CO}_{2}$ hydrogenation. J. Mol. Catal. A Chem., 345: 60-68.

[25] Fujitani, T., Saito, M., Kanai, Y., Kakumoto, T., Watanabe, T., Nakamura, J., Uchijima, T. (1994). The role of metal oxides in promoting a copper catalyst for methanol synthesis. Catal. Lett., 25: 271-276.

[26] Toyir, J., de la Piscina, P.R., Fierron, J.L.G., Homs, N. (2001). Highly effective conversion of $\mathrm{CO}_{2}$ to methanol over supported and promoted copper-based catalysts: influence of support and promoter. Appl. Catal., 29: 207215.

[27] Inui, T., Takeguch, T. (1991). Effective conversion of carbon dioxide and hydrogen to hydrocarbons. Catal. Today., 10: 95-106.

[28] Cai, W., de la Piscina, P.R., Toyir, J., Homs, N. (2015). $\mathrm{CO}_{2}$ hydrogenation to methanol over CuZnGa catalysts prepared using microwave-assisted methods. Catal. Today., 242: 193-199.

[29] Fujimoto, K., Yu, Y. (1993). CO hydrogenation to methanol. New Aspects of Spillover Effect in Catalysis: For Development of Highly Active Catalysts. Studies in Surface Science and Catalysis, 77: 369-393.

[30] Sahibzada, M., Chadwick, D., Metcalfe, I.S. (1996). Hydrogenation of carbon dioxide to methanol over palladium-promoted $\mathrm{Cu} / \mathrm{ZnO} / \mathrm{Al}_{2} \mathrm{O}_{3}$ catalysts. Catal. Today., 29: 367-372.

[31] Gotti, A., Prins, R. (1998). Basic metal oxides as co-catalysts in the conversion of synthesis 
gas to methanol on supported palladium catalysts. J. Catal., 175: 302-311.

[32] Melian-Cabrera, I., Granados, M.L., Terreros, P., Fierro, J.L.G. (1998). $\mathrm{CO}_{2}$ hydrogenation over Pd-modified methanol synthesis catalysts. Catal. Today., 45: 251-256.

[33] Klier, K. (1982). Methanol synthesis. Adv. Catal., 31: 243-313.

[34] Nonneman, L.E.Y., Ponet, V. (1990). On the problem of the activity in methanol synthesis of supported, unpromoted copper catalysts. Catal. Lett., 7: 213-217.

[35] Herman, R.G., Klier, K., Simmons, G., Finn, B.P., Bulko, J.W., Kobylinski, T.P. (1979). Catalytic synthesis of methanol from $\mathrm{CO} \mathrm{H}_{2}$ : I. Phase composition, electronic properties, and activities of the $\mathrm{Cu} / \mathrm{ZnO} / \mathrm{M}_{2} \mathrm{O}_{3}$ catalysts. J. Catal., 56: 407-429.

[36] Kau, L., Hodgson, K.O., Solomon, E.I. (1989). X-ray absorption edge and EXAFS study of the copper sites in zinc oxide methanol synthesis catalysts. J. Am. Chem. Soc., 111: 7103-7109.

[37] Okamoto, Y., Fukino, K., Imanaka, T., Teranishi, S. (1983). Surface characterization of copper(II) oxide-zinc oxide methanolsynthesis catalysts by x-ray photoelectron spectroscopy. 1. Precursor and calcined catalysts. J. Phys. Chem., 87: 3740-3747.

[38] Chinchen, G.C., Waugh, K.C., Whan, D.A. (1986). The activity and state of the copper surface in methanol synthesis catalysts. Appl. Catal., 25: 101-107.

[39] Denise, B., Sneeden, R.P.A., Beguin, B., Cherifi, O. (1987). Supported copper catalysts in the synthesis of methanol: $\mathrm{N}_{2} \mathrm{O}$-titrations. Appl. Catal., 30: 353-363.

[40] Chinchen, G.C., Hay, C.M., Vandervell, H.D., Waugh, K.C. (1987). The measurement of copper surface areas by reactive frontal chromatography. J. Catal.,103: 79-86.

[41] Li, D., Xu, S., Cai, Y., Chen, C., Zhan, Y., Jiang, L. (2017). Characterization and Catalytic Performance of $\mathrm{Cu} / \mathrm{ZnO} / \mathrm{Al}_{2} \mathrm{O}_{3}$ WaterGas Shift Catalysts Derived from $\mathrm{Cu}-\mathrm{Zn}-\mathrm{Al}$ Layered Double Hydroxides. Ind. Eng. Chem. Res., 56: 3175-3183.

[42] Evans, J.W., Wainwright, M.S., Bridgewater, A.J., Young, D.J. (1983). On the determination of copper surface area by reaction with nitrous oxide. Appl. Catal., 7: 75-83.

[43] Meli'an-Cabrera, I., L'opez-ranados, M., Fierro, J.L.G. (2002). Reverse topotactic transformation of a $\mathrm{Cu}-\mathrm{Zn}-\mathrm{Al}$ catalyst during wet $\mathrm{Pd}$ impregnation: relevance for the performance in methanol synthesis from $\mathrm{CO}_{2} / \mathrm{H}_{2}$ mixtures. J. Catal., 210: 273-284.
[44] Ernsta, K.H., Campbell, C.T., Moretti, G. (1992). Kinetics of the reverse water-gas shift reaction over $\mathrm{Cu}$ (110). J. Catal., 134: 66-74.

[45] Witoon, T., Permsirivanich, T., Donphai, W., Jaree, A., Chareonpanich, M. (2013). $\mathrm{CO}_{2}$ hydrogenation to methanol over $\mathrm{Cu} / \mathrm{ZnO}$ nanocatalysts prepared via a chitosan-assisted coprecipitation method. Fuel. Proc. Tech., 116: 72-78.

[46] Habibi, M.H., Karimi, B. (2014). Preparation of nanostructure $\mathrm{CuO} / \mathrm{ZnO}$ mixed oxide by sol-gel thermal decomposition of a $\mathrm{CuCO}_{3}$ and $\mathrm{ZnCO}_{3}$ : TG, DTG, XRD, FESEM, and DRS investigations. J. Ind. Eng. Chem., 20: 925-229.

[47] Lei, H., Hou, Z., Xie, J. (2016). Hydrogenation of $\mathrm{CO}_{2}$ to $\mathrm{CH}_{3} \mathrm{OH}$ over $\mathrm{CuO} / \mathrm{ZnO} / \mathrm{Al}_{2} \mathrm{O}_{3}$ catalysts prepared via a solvent-free routine, Fuel., 164: 191-198.

[48] Dong, X., Li, F., Zhao, N., Tan, Y., Wang, J., Xiao, F. (2017). $\mathrm{CO}_{2}$ hydrogenation to methanol over $\mathrm{Cu} / \mathrm{Zn} / \mathrm{Al} / \mathrm{Zr}$ catalysts prepared by liquid reduction. Chin. J. Catal., 38: 717-725.

[49] Li, L., Mao, D., Yu, J., Guo, X. (2015). Highly selective hydrogenation of $\mathrm{CO}_{2}$ to methanol over $\mathrm{CuO}-\mathrm{ZnO}-\mathrm{ZrO}_{2}$ catalysts prepared by a surfactant-assisted co-precipitation method. J. Power. Sources., 279: 394-404.

[50] Gao, P., Li, F., Xiao, F., Zhao, N., Sun, N., Wei, W., Sun. Y. (2012). Preparation and activity of $\mathrm{Cu} / \mathrm{Zn} / \mathrm{Al} / \mathrm{Zr}$ catalysts via hydrotalcite-containing precursors for methanol synthesis from $\mathrm{CO}_{2}$ hydrogenation. Catal. Sci. Technol., 2: 1447-1454.

[51] Fujita, S.I., Usui, M.,Takezawa, N. (1992). Mechanism of the reverse water gas shift reaction over $\mathrm{Cu} / \mathrm{ZnO}$ catalyst. J. Catal., 134: 220-225.

[52] Gine's, M.J.L., Marchi, A.J., Apesteguı'a, C.R. (1997). Kinetic study of the reverse water-gas shift reaction over $\mathrm{CuO} / \mathrm{ZnO} / \mathrm{Al}_{2} \mathrm{O}_{3}$ catalysts, Catal. A., 154: 155-171.

[53] Schilke, T.C., Fisher, I.A., Bell, A.T. (1999). In Situ Infrared Study of Methanol Synthesis from $\mathrm{CO}_{2} / \mathrm{H}_{2}$ on Titania and Zirconia Promoted $\mathrm{Cu} / \mathrm{SiO}_{2}$, J. Catal., 184: 144-156.

[54] Yoshihara, J., Campbell, C.T. (1996). Methanol Synthesis and Reverse Water-Gas Shift Kinetics over $\mathrm{Cu}(110)$ Model Catalysts: Structural Sensitivity. J. Catal., 161: 776-782.

[55] Yoshihara, J., Parker, S.C., Schafer, A., Campbell, C.T. (1995). Methanol synthesis and reverse water-gas shift kinetics over clean polycrystalline copper. Catal. Lett., 31: 313-324.

[56] Jung, K.D., Bell., A.T. (2000). Role of hydrogen spillover in methanol synthesis over Cu/ZrO ${ }_{2 .}$ J. Catal., 193: 207-223. 
[57] Chiavassa, D.L., Collins, S.E., Bonivardi, A.L., Baltanas, M.A. (2009). Methanol synthesis from $\mathrm{CO}_{2} / \mathrm{H}_{2}$ using $\mathrm{Ga}_{2} \mathrm{O}_{3}-\mathrm{Pd} /$ silica catalysts: kinetic modeling. Chem. Eng. J., 150: 204-212.

[58] Lim, H.W., Park, M.J., Kang, S.H., Chae, H.J., Bae, J.W., Jun, K.W. (2009). Modeling of the kinetics for methanol synthesis using $\mathrm{Cu} / \mathrm{ZnO} / \mathrm{Al}_{2} \mathrm{O}_{3} / \mathrm{ZrO}_{2}$ catalyst: influence of carbon dioxide during hydrogenation. Ind. Eng. Chem. Res., 48: 10448-10455.

[59] Fujita, S., Usui, M., Ito, H.,Takezawa, N. (1995). Mechanisms of methanol synthesis from carbon dioxide and from carbon monoxide at atmospheric pressure over $\mathrm{Cu} / \mathrm{ZnO}$. J. Catal.,157: 403-413.
[60] Bailey, S., Froment, G.F., Snoeck, J.W., Waugh, K.C. (1995). A drifts study of the morphology and surface adsorbate composition of an operating methanol synthesis catalys. Catal. Lett., 30: 99-111.

[61] Chinchen, M.S., Spencer, K.C., Waugh-Whan, D.A. (1987). Promotion of methanol synthesis and the water-gas shift reactions by adsorbed oxygen on supported copper catalysts. $J$. Chem. Soc., Faraday Trans. 1., 83: 21932212. 